\title{
Advances of nanotechnology in agro-environmental studies
}

\author{
Stefania Mura, ${ }^{1}$ Giovanna Seddaiu, ${ }^{1}$ Fabio Bacchini, ${ }^{2}$ Pier Paolo Roggero, ${ }^{1}$ \\ Gian Franco Greppi ${ }^{1,3}$ \\ ${ }^{1}$ Dipartimento di Agraria e Nucleo di Ricerca sulla Desertificazione, Università di Sassari; ${ }^{2}$ LEA - \\ Laboratorio di Epistemologia Applicata, DADU - Dipartimento di Architettura, Design \\ Urbanistica, Università di Sassari; ${ }^{3}$ CNBS-Centro Nano Bionanotecnologie Sardegna e \\ Dipartimento di Agraria, Università di Sassari, Italy
}

\begin{abstract}
With the increase in the world population and the demand for food, new agricultural practices have been developed to improve food production through the use of more effective pesticides and fertilisers. These technologies can lead to an uncontrolled release of undesired substances into the environment, with the potential to contaminate soil and groundwater. Today, nanotechnology represents a promising approach to improve agricultural production and remediate polluted sites. This paper reviews the recent applications of nanotechnologies in agro-environmental studies with particular attention to the fate of nanomaterials once introduced in water and soil, to the advantages of their use and their possible toxicology. Findings show that the use of nanomaterials can improve the quality of the environment and help detect and remediate polluted sites. Only a small number of nanomaterials demonstrated potential toxic effects. These are discussed in detail.
\end{abstract}

Correspondence: Giovanna Seddaiu, Dipartimento di Agraria e Nucleo di Ricerca sulla Desertificazione, Università di Sassari, via E. De Nicola, 07100 Sassari, Italy. Tel. +39.079 .229392 .

E-mail: gseddaiu@uniss.it

Key words: nanoparticles, soil, water, remediaton, photocatalysis, toxicity, environment, desertification.

Funding: the work was supported by the IDRISK project, a Grant financed by RAS (Regione Autonoma della Sardegna, PO Sardegna FSE 2007-2013 L.R. 7/2007 - Promozione della ricerca scientifica e dell'innovazione tecnologica in Sardegna) and by a Master and Back programme funded by the Autonomous Regional Government of Sardinia.

Conflict of interests: the authors declare no potential conflict of interests.

Received for publication: 7 January 2013.

Revision received: 31 May 2013.

Accepted for publication: 1 June 2013.

(OCopyright S. Mura et al., 2013

Licensee PAGEPress, Italy

Italian Journal of Agronomy 2013; 8:e18

doi:10.4081/ija.2013.e18

This article is distributed under the terms of the Creative Commons Attribution Noncommercial License (by-nc 3.0) which permits any noncommercial use, distribution, and reproduction in any medium, provided the original author(s) and source are credited.

\section{Introduction}

Since the industrial revolution, human activities have been highly dependent on a variety of chemical and physical processes that are either pollution-borne or energy-intensive. However, chemical agriculture, developed from the widespread use of agro-chemicals, can be a mixed blessing rather than a curse in disguise for mankind (Sinha, 2009). Over the years, it has increased the quantity of food produced but has severely affected soil fertility and the environmental quality of natural resources. Adverse effects of agro-chemicals on the agroecosystems (i.e. soil, flora, fauna and water bodies), and also on the health of the farmers using them and the society consuming the chemically grown food, have now started to become more evident all over the world (Tiju and Morrison, 2006). As a result, the use of green technology to mitigate the environmental damage is becoming a high priority. The use of bio-based technologies represents the biggest part of green technology according to which human needs, such as food, energy, commodities, medicine, pollution control, etc., should be satisfied through bioconversion and biorefinery processes featuring pollutionfree strategies and energy saving (Feehan et al., 2009; Jones et al., 2009; Siegmann et al., 2008).

In this context, the advent of nanotechnologies has been heralded by governments, the media and many scientific communities as the next big thing (Chen and Yada, 2011). The United States (US) government is spending over 1 billion dollars per year on the development of nanotechnologies, and the European Union (EU) and Japan are heavily involved in their development and application, as are China and India (Miller and Senjen, 2008).

Nanotechnology is a science that deals with objects of nanometer size $(1-100 \mathrm{~nm})$ for at least one dimension (Figure 1). Nanotechnologies enable other technologies and will, therefore, will mostly result in the production of intermediate goods. Because nanotechnologies connect disciplines as diverse as, amongst others, physics, chemistry, genetics, information and communication technologies, and cognitive sciences, they offer the foundation of the socalled nano-bio-info-cogno convergence. Hence, the current definition based on physical size should be complemented by adding a limit of the specific surface area. Solid spheres of $100 \mathrm{~nm}$ with unit density have a specific surface area of $60 \mathrm{~m}^{2} \mathrm{~g}^{-1}$. The Royal Society defines nanotechnologies as the design, characterization, production and application of structures, devices and systems by controlling shape and size at nanometer scale (RSRAE, 2004) It is able to control matter at this length scale, at a molecular or atomic level, and to create structures with new properties and organisation. The EU (European Commission, 2011) defines Nanomaterial as a natural, incidental or manufactured material containing particles, in an unbound state or as an agglomerate and where, for $50 \%$ or more of the particles in the number size distribution, one or more external dimensions is in the size range $1 \mathrm{~nm}-100 \mathrm{~nm}$. The unique properties of nanomaterials dif- 
fer substantially from bulk materials; in fact, at this scale, matter behaves differently from the laws of applied quantum physics creating new objects with different properties (Maurice and Hochella, 2008). Nanomaterials with one or more external dimensions, or an internal structure, at a nanoscale could exhibit novel characteristics compared to the same material at a larger scale. Nanoparticles (NPs) are the best-known nanomaterials; they have predominant surface effects (Fiorani, 2005) for the high proportion of the atoms located on their surface that leads to a relevant increase in their reactivity. Furthermore, these particles are subjected to phase transformation (Gilbert et al., 2003). In fact, changing their size and shape also changes their identity, as is evident in quantum dots. A reduction in size to the nanoscale changes the characteristics of particles, primarily due to the increased surface to volume ratio. There are as yet no paradigms to anticipate the significance of any of these changes in characteristics, so the safety evaluation of NPs and nanostructures cannot rely on the toxicological and ecotoxicological profile of the bulk material that has been historically determined. Nanoparticle forms of various chemicals (metals, carbon, other inorganic and organic chemicals) are being developed to produce new products that have properties that are qualitatively or quantitatively different from their other physical forms. It would not be surprising, therefore, if their interactions with and in biological systems are also altered. The biological behaviour of NPs is determined by the chemical composition, including coatings on the surface, the decrease in size and corresponding shifts in chemical and physical properties, the associated increase in surface to volume ratio, and the shape. In addition, aggregations of NPs may have an effect on their biological behaviour as well.

Nanotechnology will leave no field untouched by its ground breaking scientific innovations. General applications of nanomaterials are found in water purification, wastewater treatments, industrial and household

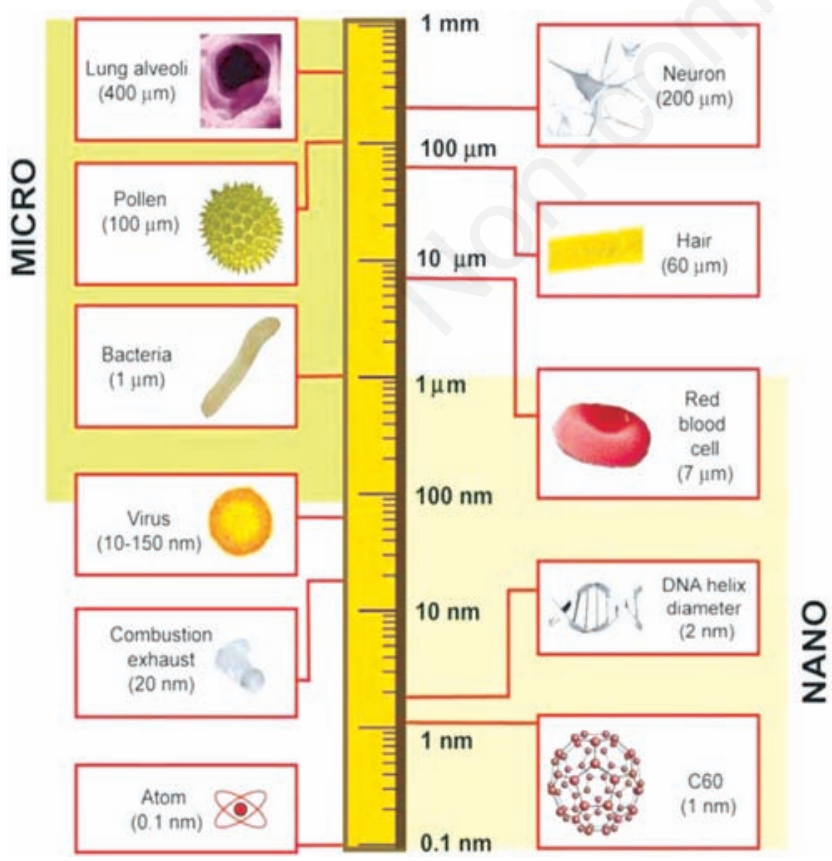

Figure 1. Logarithmical length scale showing size of nanomaterials compared to biological components and definition of nano and micro sizes (from Buzea et al., 2007). purposes, smart sensor development, environmental remediation, food industry for products processing and packaging, medicine, etc. (Bradley et al., 2011; Wei et al., 2007; Lee et al., 2010; Li et al., 2008). The application of nanotechnology to the agricultural and food industries was first addressed by a United States Department of Agriculture roadmap published in September 2003 (USDA, 2003). So far, the use of nanotechnology in agriculture has been mostly theoretical, but it has begun to have, and will continue to have, a significant effect in the main areas of the food industry: development of new functional materials, product development, and design of methods and instrumentation for food safety and bio-security. The effects on society as a whole will be dramatic. As nanotechnologies have already revolutionised the health care, textile industry, information and communication technology, and energy sectors, such as the release in the market of antibacterial dressings, transparent sunscreen lotions, stain-resistant fabrics, scratch-free paints for cars, and self-cleaning windows, nanotechnology will likely transform the entire food industry, changing the way food is produced, processed, packaged, transported, and consumed (Figure 2). However, the application of nanotechnologies in the agronomic and environmental domains is still in its infancy (Gonzalez-Melendi et al., 2008). Major challenges related to agriculture, such as low productivity in arable areas, large non-arable areas, shrinkage of arable lands, wastage of inputs such as water, fertilisers, pesticides, wastage of products and, of course, food security can be addressed through various applications of nanotechnology. Accordingly, there will be a greater pressure on resources (in particular water and crops). The land surface dedicated to crop production worldwide will be increased in order to meet demands on food energy and other industrial uses. Therefore, the environmental impact in some areas could be high (Colvin, 2003). In order to obtain commodities and other feedstock in a sustainable way it is necessary to improve the current production systems and control the environmental impact, acting on: i) agriculture; ii) water management and use; iii) food processing.

Exploiting nanotechnologies could help to improve agricultural practices and to deal with environmental problems (Kumar, 2010). In fact, the formation of dangerous by products could be prevented through the control of emissions using green technologies and contaminants could

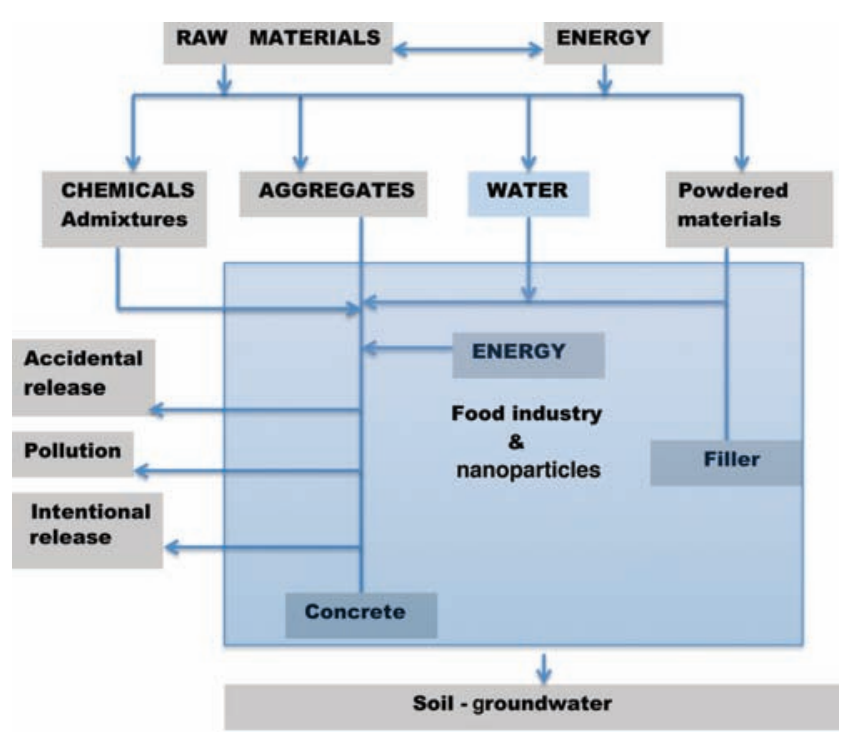

Figure 2. Resource consumption flow and emissions in the food industry (from Nowack and Bucheli, 2007, with permission). 
be detected or removed from water sources and soil through the remediation of polluted aquifers or sites (Baruah and Dutta, 2009).

This review discusses some applications of engineered NPs and nanotechnology in the agricultural production chain. The fate of nanomaterials once introduced in water and soil, and the advantages of their use and possible toxicity risks are also discussed.

\section{Applications of nanotechnology in the agricultural sector}

Applications of nanotechnology in agriculture are still in their infan- cy and not many studies have been carried out in this field (Baruah and Dutta, 2009). Despite the scientific and technical knowledge achieved so far, in many conditions, crop productivity potential has not been fully realised. This is attributed to low nutrient and water use efficiency of crops and stiff competition from weeds and crop pests (Schroeder et al., 2005). Nanotechnology offers a new scientific approach to break this yield barrier and may improve our understanding of the biology of different crops. This has the potential to enhance yields and nutritional values, and improve systems for monitoring environmental conditions and delivering nutrients or pesticides as appropriate. In addition, it can offer solutions to meet the challenges of food security and of environmental remediation (Table 1).

The use of nanotechnology in agriculture shows promise. However, research into most applications is still ongoing, such as in the field of

Table 1. A synthesis of the applications of nanotechnology in the agro-food sector.

\begin{tabular}{|c|c|c|}
\hline Chain phase & Application & Nanotechnology and functions \\
\hline $\begin{array}{l}\text { Energy and conversion storage, } \\
\text { production }\end{array}$ & $\begin{array}{l}\text { Novel hydrogen storage based on carbon nanotubes } \\
\text { Photovoltaic cells and organic light emitters } \\
\text { (Quantum dots) batteries for solar cells (Carbon nanotubes) }\end{array}$ & $\begin{array}{l}\text { Cheaper and clean energy } \\
\text { Low weight and low cost solar cells } \\
\text { Improved rechargeable batteries }\end{array}$ \\
\hline Agricultural productivity & $\begin{array}{l}\text { Nanoporous Zeolites for enhancement slow release } \\
\text { and efficient production that requires delivery } \\
\text { of fertilisers, fewer inputs nutrients and drugs }\end{array}$ & $\begin{array}{l}\text { Nanosensors for soil quality } \\
\text { Nanochips for identity preservation and tracking } \\
\text { Nanoparticles to deliver DNA to plants in genetic } \\
\text { Nanosensors for monitoring plant microenvironment } \\
\text { and its changes and in greenhouse production } \\
\text { of protected species }\end{array}$ \\
\hline $\begin{array}{l}\text { Food processing and storage } \\
\text { and plant health monitoring }\end{array}$ & $\begin{array}{l}\text { Cheaper, safer food products film for food } \\
\text { packaging with longer storage life } \\
\text { More rapid deployment of nutrients nanosensors } \\
\text { and safer control strategies } \\
\text { Composite film coatings detection }\end{array}$ & $\begin{array}{l}\text { Antimicrobial nano emulsions for decontamination } \\
\text { Antigen detection at nanoscale } \\
\text { Nanosensors for monitoring soil conditions and crop growth } \\
\text { Nanocapsules for efficient delivery of pesticides, fertilisers } \\
\text { and other agrichemicals }\end{array}$ \\
\hline Agricultural production & Water purification/soil cleaning & $\begin{array}{l}\text { Nanocomposites in plastic } \\
\text { Nanospray on food commodities } \\
\text { Binds and colours micro-organisms } \\
\text { Hand-held devices } \\
\text { Detection of contaminants, mycotoxins and microorganism } \\
\text { Nano-emulsions, encapsulates } \\
\text { Increased efficacy and water solubility } \\
\text { Triggered release nano-encapsulates } \\
\text { Triggered (local) release }\end{array}$ \\
\hline $\begin{array}{l}\text { Production } \\
\text { and processing of food }\end{array}$ & $\begin{array}{l}\text { Food production } \\
\text { removal } \\
\text { Refrigerators, storage containers, food preparation equipment }\end{array}$ & $\begin{array}{l}\text { Filters with nano-pores NPs. Pathogen/contaminant } \\
\text { Removal/catalysation/oxidation of contaminants } \\
\text { Nano-ceramic devices }\end{array}$ \\
\hline & & Large reactive surface area \\
\hline Conservation & Packaging materials & $\begin{array}{l}\text { Incorporated nano-sized particles, mostly silver, occasionally } \\
\text { zinc oxide } \\
\text { Anti-bacterial coating } \\
\text { Nano-sized silver sprays. Anti-bacterial action } \\
\text { Incorporated sensors. Detection of food deterioration } \\
\text { Monitoring storage conditions } \\
\text { Incorporated NPs } \\
\text { Increasing barrier properties, strength of materials }\end{array}$ \\
\hline Functional food consumption & Supplements/additives & $\begin{array}{l}\text { Incorporated active NPs. Oxygen scavenging, prevention of } \\
\text { growth of pathogens } \\
\text { Colloidal metal NPs. Claimed enhanced desirable uptake } \\
\text { of metal } \\
\text { Delivery systems nano-clusters } \\
\text { Protection and (targeted) delivery of content } \\
\text { Nano-sized/-clustered food/drinks (nutrients) } \\
\text { Claimed enhanced uptake }\end{array}$ \\
\hline
\end{tabular}

NPs, nanoparticles (adapted from Bouwmeester et al., 2009, with permission). 
crop breeding and production of more selective, effective and easier-todose plant protection products (EFSA, 2009; FAO/WHO, 2010; Nair et al., 2010).

Some studies demonstrated the role of nanomaterials in enhancing seed germination rates in tomato (Khodakovskaya et al., 2009), spinach (Zheng et al., 2005) and rice (Lin and Xing, 2007), and consequently the crop dry matter yield, at least in the early stages of growth. However, several concerns remain on the possible phytotoxicity of some types of nanomaterials (nano-sized $\mathrm{Zn}$, nano- $\mathrm{Al}, \mathrm{La}_{2} \mathrm{O}_{3}, \mathrm{Gd}_{2} \mathrm{O}_{3}$, nano-Ag), depending on their composition, concentration, size and physical chemical properties (Ma et al., 2010a) and on the susceptibility of the plant species (Khot et al., 2012; Taylor and Fauquet, 2002; Torney et al., 2007). Toxicity of nanomaterials could possibly be reduced by coating them with biocompatible products before their application to seeds, increasing their effectiveness for plant germination and growth while avoiding negative impacts on seedlings (Khot $e t$ al., 2012). However, research findings are far from fully explaining the complex connections between the characteristics of NPs and plant traits with phytotoxicity (Ma et al., 2010a).

Plant production could also be increased through the development of nanomaterials that can be used as a coating layer to enable the slow release of traditional fertilisers. For example, the possible role of chitosan NPs (Corradini et al., 2010; Mura et al., 2011a) and of kaolinbased nanolayers (Liu et al., 2006) was assessed for slow release of NPK fertiliser, but further investigation is still needed (Ghormade $e t$ al., 2010).

Nanomaterials have been recently reported to have a potential role in plant protection by: i) increasing the dispersion and wettability, and the affinity to pesticide target (Bergeson, 2010; Jianhui et al., 2005); ii) providing better penetration of herbicides through cuticles and tissues of weeds (Gonzalez-Melendi et al., 2008; Perez-de-Luque and Rubiales, 2009); iii) altering viral capsids to achieve different configurations and deliver specific nucleic acids, enzymes or antimicrobial peptides acting against the parasites (Torney et al., 2007). The use of nanostructured catalysts could improve the efficiency of pesticides and herbicides, allowing lower doses to be used (Corredor et al., 2009). Perez-de-Luque and Rubiales (2009) suggested that a potential development of new nanomaterials is towards the building of agrochemicals containing different nano-substances for different functions (plant protection, fertilisation, hormones, etc.) and encapsulated separately to avoid interactions between them and degradation. In this way, several substances could be applied with the same treatment to the crop, and the nanocapsules could be regulated to release their load according to the characteristic of every loaded substance.

Some studies showed the potential use of nanotechnologies to detect microbes (Karn et al., 2009; Ma et al., 2010b) contaminants (Hillie and Hlophe, 2007), toxic pollutants (Balaji, 2006) and for monitoring soil conditions, crop growth, plant microenvironment and enzyme/substrate interactions (Gonzalez-Melendi et al., 2008). Nanotechnology can also be applied for remediation purposes through the construction of nano-photocatalysts able to degrade organic pesticides and industrial pollutants in harmless and useful products (Otto et al., 2008; Karn et al., 2009; Sidorenko et al., 2003). Filters or catalysts could also be created to reduce pollution or clean-up existing pollutants (Han et al., 2008).

This technology, combined with others such as biotechnology, can make genetic manipulation of plants easier. It allows NPs, nanofibers or nanocapsules to be used as vectors of new genetic material instead of conventional viral vectors. These new vehicles could carry a larger number of genes, as well as substances able to trigger gene expression (Miller and Senjen, 2008; Nair et al., 2010) or to control the release of genetic material over time.

Another field of application of nanotechnology is particle farming.
This yields NPs for industrial use by growing plants in defined soils (Marchiol, 2012). For example, research has shown that alfalfa plants grown in gold rich soil absorb gold NPs through their roots and accumulates them in their tissues (Gardea-Torresdey et al., 2002). The gold NPs can be mechanically separated from the plant tissue following harvest. The formation of NPs of an alloy of gold-silver-copper using plants was also reported (Haverkamp et al., 2007).

Industry has shown a great deal of interest in this area. However, examples of available products are very few and far between. Most developments seem to be currently at the research and development (R\&D) stage, and it is likely that the agriculture sector will see some large-scale applications of nanotechnologies in the future. The following list reports the main nanomaterials for applications in the agrofood sector.

\section{Nanosilver}

A growing use of nanosilver is being found in a number of consumer products, including food and health food, water, and food contact surfaces and packaging materials. Indeed, the use of nanosilver as an antimicrobial, antiodourant, and a (proclaimed) health supplement has already surpassed all other nanomaterials currently in use in different sectors (Woodrow Wilson International Centre for Scholars, 2009). Most current uses of nanosilver relate to health food and packaging applications, but its use as an additive to prepare antibacterial wheat flour was the subject of a rather recent patent application (Park, 2006).

\section{Nanosilica}

Amorphous nanosilica is known to be used in food contact surfaces and food packaging applications. Amorphous silica has been used for many years in food applications, such as in clearing processes of beers and wines, and as a free-flowing agent in powdered soups. The conventional bulk form of silica is a permitted food additive ( $\mathrm{SiO}_{2}$ INS 551), but the material may not have been tested with a focus on nanosilica. Porous silica is used in nanofiltration to remove undesired components in food and beverages such as the bitter taste in some plant extracts.

\section{Nanotitanium dioxide}

The conventional bulk form of titanium dioxide has already been approved as an additive for food use [titanium dioxide ( $\mathrm{TiO}_{2}$ ) INS 171], but the conventional form may also contain a nanosized fraction. Nanotitanium dioxide is used in a number of consumer products (e.g. paints, coatings) and its use may extend to foodstuffs. For example, a patent (US Patent US5741505) describes the potential application of nanoscale inorganic coatings directly on food surfaces to provide a barrier to moisture and oxygen, and thus improve shelf life and/or the flavour impact of foods. The materials used for the nanocoatings, intended to be applied in a continuous process as a thin amorphous film of $50 \mathrm{~nm}$ or less, include titanium dioxide (along with silicon dioxide and magnesium oxide) (Ma et al., 2010a). The main intended applications described in the patent include confectionary products. However, to our knowledge, this technology has not yet been used in any commercial application. Nanotitanium dioxide is also used as a photocatalyst in water treatment applications, especially to oxidise heavy metals and organic pollutants, and to kill microbial pathogens.

\section{Nanoselenium}

Nanoselenium is being marketed as an additive to a green tea product, with a number of (proclaimed) health benefits resulting from enhanced uptake of selenium. 


\section{Nanocalcium}

Nanocalcium salts are the subject of patent applications (Sustech GMBH \& Co, Düsseldorf, Germany; http://www.nanomat.de) for intended use in chewing gums. Nanocalcium and nanomagnesium salts are also available as health supplements.

\section{Nano-iron}

Nano-iron is available as a health supplement. Nano-iron is also used in the treatment of contaminated water, where it is claimed to decontaminate water by breaking down organic pollutants and killing microbial pathogens. Iron nanoparticle technology has received considerable attention for its potential application in groundwater treatment and site remediation. Recent studies have demonstrated the effect of zero valent iron NPs for the transformation of halogenated organic contaminants and heavy metals. In addition, several studies demonstrated that zero valent iron is effective in stabilising or destroying a host of pollutants thanks to its highly reducing character. Given this, zero valent iron (ZVI) has been proposed as one of the best reactive materials in permeable reactive barrier (PRB) technology (Scherer et al., 2000 ). With the growing application of nanotechnology in different fields, in recent years, organisms and ecosystems have been subjected to new levels of substances the consequences of which are still largely unknown (Mura et al., 2011c; Nowack and Bucheli, 2007). There is, therefore, a high degree of uncertainty concerning the long-term effects of nanomaterials on human health and the environment.

\section{Nanodiffusion in the environment}

Nanoparticles are not a human invention and have always existed naturally. For example, NPs have been found in 10,000-year old glacial ice cores (Murr et al., 2004; Murr and Garza, 2009), and there is evidence of natural NP formation in sediments at the Cretaceous-Tertiary boundary (Verma et al., 2002). If we consider atmospheric dust alone, estimates indicate approximately one billion metric tons per year produced globally (Kellogg and Griffin, 2006), and even with a fraction of this as ultrafine particles, this would be millions of tons of natural NPs. If we compare this against production estimates for manufactured nanomaterials of the order of a few thousand tons per year for each major type of material (Borm et al., 2006), it is clear that exposure to natural NPs vastly outweighs any anthropogenic production. There are several mechanisms that create NPs in the environment and these can be either geological or biological. Geological mechanisms include physicochemical weathering, authogenesis/neoformation (e.g., in soils), and volcanic activity. These geological processes typically produce inorganic NPs. Biological mechanisms typically produce organic nano-molecules, although some organisms can produce mineral granules in cells.

\section{Nanomaterials in soil}

Nanoscience is of crucial importance to the soil sciences because many natural compounds of the soils are nanoparticulate or have nanoscale features. At the nanoscale, particle-particle interactions are either dominated by weak Van der Waals forces, stronger polar and electrostatic interactions, or covalent interactions. Depending on the viscosity and polarisability of the fluid, particle aggregation is determined by the interparticle interaction. Modifying the surface layer can enhance or hinder the tendency of a colloid to coagulate. In liquids, par- ticle charge can be stabilised by electrochemical processes at surfaces. The details of nanoparticle-nanoparticle interaction forces and nanoparticle-fluid interactions are of key importance to describe physical and chemical processes, and the temporal evolution of free NPs.

Different nanomaterials can be found in soil: nanominerals that only exist in the nanoparticle range and mineral NPs that are minerals in nanosize range but also exist at larger sizes (Maurice and Hochella, 2008). Different nanomaterials are present in soils as nanoscale aggregates of natural organic matter, bacterial appendages, organic and inorganic particles as zeolites, humic and fulvic acids, allophane and imogolite, hydroxides and aluminosilicate, clay minerals, amorfous substance and other nanominerals as ferrihydrite, Fe (hydr)oxides (hematite, goethite, maghemite, lepidocrocite, magnetite), Mn (hydr)oxides, uraninite ( $\left.\mathrm{UO}_{2}\right)$ and swelling clays (montmorillonite). In particular, different classes of inorganic materials such as silicates (clay and mica), oxides/hydroxides $(\mathrm{MnO})$, carbonates $\left(\mathrm{CaCO}_{3}\right)$, phosphates, metal sulphides $(\mathrm{ZnS})$ or organic materials as cell fractions, macromolecules or biocolloids (bacteria) can be found in soils (Maurice and Hochella, 2008). Manufactured or engineered NPs can also be found in soils. These can be released in the environment either unintentionally (corrosion or combustion of products) or intentionally in different forms: metal oxides [ $\mathrm{TiO}_{2}$, zinc oxide $\left.(\mathrm{ZnO})\right]$, semiconductor materials (quantum dots), carbon derived nanomaterials (carbon nanotubes), zero valent metals (zero valent iron), nanopolymers. These classes of compounds come from the different industries (e.g. fullerene from electronic and optic, $\mathrm{CeO}_{2}$ from automotive, AgNPs from medical devices, $\mathrm{ZnO}$ from solar cells, $\mathrm{TiO}_{2}$ from cosmetics and painting), and significant amounts of these nanomaterials are deposited in soil (Qafoku, 2010).

Nanotechnology could have several applications in soil science (Lal, 2007). As discussed above, the use of nanofertilisers can facilitate nutrient transport to the rhizosphere when needed, and in more suitable amounts and composition, thereby improving efficiency of use. NPs locked onto the roots can also enhance elemental uptake. The nanoscale delivery vehicles may be designed to fix the surrounding soil particles or organic matter (Johnston, 2010), allowing more efficient release mechanisms. These features could promote the active substances to be taken up at a slower rate throughout crop growth, avoiding temporal overdoses, and minimising input and waste (Chen and Yada, 2011). The slow release of nutrients into the environment could be achieved by using zeolites; these are a group of naturally occurring minerals with a honeycomb-like layered crystal structure.

Fertiliser particles can be coated with nanomembranes that facilitate slow and steady release of nutrients. Coating and cementing of nano and subnano-composites are capable of regulating the release of nutrients from the fertiliser capsule (Liu et al., 2006). A patented nano-composite consisting of nitrogen, phosphorus, potassiunm (NPK), micronutrients, mannose and amino acids that increases the uptake and utilisation of nutrients by grain crops has been reported by Jinghua (2004). Nitrogen leaching was found to be lowered when slowrelease fertilisers were coated by nanomaterials such as plastic-starch composites applied to wheat (Zhang et al., 2006).

The installation of nanosensors, or nanoscale wireless sensors, in farmers' field is being applied to enable the real time monitoring of soil and the early detection of potential problems such as soil nutrient depletion and water deficit (Scott and Chen, 2003). In this context, nanosensors can be a means to extend the logic of precision farming in novel ways in order to detect and rectify agronomic problems in very short time frames. Nanomaterials, such as hydrogels and zeolites, were reported to be useful to improve water-holding capacity of the soil (ElSalmawi, 2007) and to absorb environmental contaminants (Yuan, 2004; Baruah and Dutta, 2009). 


\section{Applications of nanoparticles in soil remediation}

Nanoparticles can be applied in different ways in soil remediation thanks to their sorption capacity. NPs can be used to interact with polymorphs, minerals, contaminants and nutrients. In particular, they can be used to absorb metal and anionic contaminants [arsenic (As), chromium, lead $(\mathrm{Pb})$, mercury, selenium, copper $(\mathrm{Cu})$, uranium], natural organic matter, organic acids, and heavy metals (Changa and Chen, 2005; Mercier and Pinnavaia, 1997; Yang et al., 2006). Contaminant sequestration is achieved by surface complexation or encapsulation in interior interfaces of NP aggregates (Lü et al., 2007; Tungittiplakorn et al., 2005) that can also be used for groundwater cleanup and remediation. In particular, copper oxide (Cu0) NPs have been used for As III and V adsorption (Martinson and Reddy, 2009), zero valent iron NPs for remediation of organic pollutants (Ponder $e t$ al., 2001), nanoporous apatite for removal of radionuclides and contaminants (El Asria et al., 2009).

\section{Processes affecting nanoparticles behaviour in soils}

Nanoparticles are involved in natural processes as soil development and nutrient cycling but can also act as vehicles of contaminant transport, alter the bioavailability of substances and hence their toxicity. Particles in the nanoscale (colloids) are abundant in all environmental compartments. These nanophases are composed of natural organic matter (e.g. humic substances), are biota itself (viruses, bacteria including pathogens), inorganic particles (clays, oxides or carbonates) or originate either from engineering (nanotechnology) or from wear/combustion/corrosion. Different processes can influence NP behaviour once introduced in soil (Qafoku, 2010; Tourinho et al., 2012).

\section{Growth}

Nanocrystals grow thanks to a self-assembly of primary NPs in an irreversible and specific mode, obtaining an oriented aggregation. Another non-classical method provides the progressive inclusion of defects into initial defect-free nanocrystals.

\section{Stability}

NPs are more stable when they have low surface energy and, among the geochemical variables that influence NPs stability, solution $\mathrm{pH}$ is the most important. Other parameters are the attachment of adsorbed ions or organic compounds that usually stabilise NPs and control their structure, size and composition.

\section{Phase transformation}

Phase transformation is an important process in soil that affects contaminant mobility. In fact, new mineral NPs are formed in soil when they interact with contaminants, leading to a change in their behaviour.

\section{Aggregation}

Spontaneous aggregation is due to attractive interactions with Van der Waals forces between NPs. Once aggregated, the NPs can precipitate and can barely be transported by water. In this way, the ability of NPs to adsorb and carry organic chemicals decreases. Factors that affect NPs aggregation are: particle shape, size, surface area, surface charge and surface coatings. In particular, $\mathrm{pH}$ and ionic strength control NP aggregation. Coating NPs with surface functional groups or organic molecules (surfactants, biopolymers as alginic acid, starch, proteins, phospholipids) can alter their surface charge or their steric interactions, promoting NPs dispersion.

\section{Mobility}

It is commonly assumed that NPs will be highly mobile in porous media because they are much smaller than the relevant pore spaces; but this is an oversimplification. In general, the mobility of NPs in saturated environmental porous media is determined by the product of the number of nanoparticle collisions with the porous medium per unit transport distance, and the probability that any collision will result in removal of the nanoparticle from the flow system (i.e. the sticking coefficient). This has led to considerable interest in surface modification of NPs to increase transport distances.

\section{Aging}

Over time, NPs can be coated with thin layers of other phases leading to a decrease in surface area and reactivity, and an increase in structural defects.

\section{Surface area}

This is defined as the surface area of a sphere $\mathrm{A} /=3 / \mathrm{r}$. As shown by the formula, smaller particles have a larger surface area and because of their large surface area and surface defects, NPs in soil are very reactive.

\section{Morphology}

Various definitions have been given for nanosize, but most invoke (or imply) the notion that there is a size regime between that of molecules and materials where particles have properties that are unique, or at least qualitatively different than those of larger particles. The most compelling examples of such properties arise only for particles smaller than approximately $10 \mathrm{~nm}$, where particle size approaches the lengthscale of certain molecular properties.

\section{Risks}

This discussion of the morphology, reactivity, and mobility of NPs in the context of environmental remediation demonstrates that w still do not have a complete understanding of the basic processes involved in this technology. Specifically, with respect to in situ applications to remediation of environmental porous media, there has still not been any research and development that directly and substantially addresses the issue of risk. This dilemma of how (or whether) to regulate the application of NPs to remediation should soon be resolved as the results from ongoing studies become available. Until then, risk assessment regarding in situ applications of NPs in remediation will continue to be based largely on extrapolations from considerations developed from studies of related, but potentially quite different, contexts where NPs occur in the environment.

Some methods for assessing the environmental distribution of nanomaterials have been described (Christian et al., 2008; Hassellöv et al., 2008; Klaine et al., 2008; Tiede et al., 2008). These continue to be developed so that the complex issues of fate in different media may be addressed. Nevertheless, much information is still needed in this area.

\section{Other factors}

Other factors affecting NPs' properties are hydration, temperature, impurities, $\mathrm{pH}$, ionic strength, and other characteristics of the media (Qafoku, 2010). 


\section{Nanoparticles mobility in soil}

Nanoparticles movement in soil is not affected by gravitational settling but is guided by Brownian motion into the soil pores. In particular, soils are composed of micropores (network of humic materials and soil particles) and macropores; single NPs can enter into the micropores and if they are sorbed on mobile colloids, the mobility is highly enhanced, while aggregates of NPs remain in the macropores, and if sorbed on non-mobile particles their mobility is inhibited. The attachment between NPs and soil molecules depends on the shape of NPs and the collector and on the different properties that change the environment surrounding the particles (Figure 3). Therefore, soil conditions can enhance or inhibite NP mobility (Fang et al., 2009). Ben-Moshe (2010) demonstrated that humic acids in soils and aquifers and the ionic strength of resident water can dramatically influence NP mobility of different types of metal oxides NPs [iron oxide $\left(\mathrm{Fe}_{3} \mathrm{O}_{4}\right), \mathrm{TiO}_{2}, \mathrm{CuO}$, and $\mathrm{ZnO}$ ], obtaining the highest mobility for $\mathrm{TiO}_{2} \mathrm{NPs}$. This may influence the monitoring of NP composition, and the fate of soil nutrients, organic pollutants and contaminants.

\section{Nanoparticle toxicity in soil}

In recent years, there has been a strong interest in the use of NPs in soils for different applications, considering NPs as environmentally benign materials, as reported in different papers (Mueller and Nowack, 2010; Zhan, 2009). However, researchers are developing new ways to monitor possible NP toxicity (Grieger et al., 2010; Karn et al., 2009) and to evaluate the benefits or risks to organisms of interest in soil science, such as bacteria, fungi, plants and other living beings (fish, rats, etc.). In particular, it was found that $\mathrm{TiO}_{2}, \mathrm{SiO}_{2}, \mathrm{ZnO}$ NPs suspended in water for Bacillus subtilis and Escherichia. coli are toxic for Gram positive and negative, and in the first ecotoxicological test for the earthworm Eisenia fetida, AgNPs produced reproductive failure and an avoidance mechanism of this pathogen in soils contaminated by this type of NPs (Heckmann et al., 2011; Mura et al., 2012a, 2012b; Shoults-Wilson et al., 2011). Negative effects of NPs were also demonstrated on soil bacterial communities that were altered by $\mathrm{ZnO} \mathrm{NPs}$, reducing the microbial biomass and diversity (Ge et al., 2011). Furthermore, soil enzyme activities were influenced by treatments with $\mathrm{ZnO} \mathrm{NPs}$, with an especially large decrease in dehydrogenase activity in response to $\mathrm{Zn}^{2+}$. With this treatment, also biomass and root length decreased, showing a phytotoxicity due to immobilisation and aggregation of NPs in the soil (Kim et al., 2011). Toxicity of ZnO NPs was also demonstrated on ryegrass and in corn where it inhibited germination (Lin and Xing, 2007). Other experiments carried out in plants showed that aluminium oxide NPs and rare earth oxide NPs can be toxic to a variety of crops (carrots, cabbage, soybeans, corn, cucumbers) as inhibitors of root elongation (Ma et al., 2010b). NPs can also be absorbed from soil into plants, as demonstrated in a study on gold NPs (Gardea-Torresdey et al., 2002). The effects that these new materials can have on a living organism once absorbed are far from understood and the difficult question is are NPs taken up into plants toxic when consumed by animals and humans?

Assessing the environmental risk requires a clear understanding on NP mobility, bioavailability, reactivity, ecotoxicity and persistency. Currently, not much is known about biodegradation of nanomaterials or whether biodegradation products may be toxic.

\section{Nanomaterials in water}

A 2004 US-EPA report (http://www.epa.gov/roe/) estimated that it will take 30-35 years and cost up to $\$ 250$ billion to clean up the nation's hazardous waste sites. EPA anticipates that these high costs will provide an incentive to develop and implement clean-up strategies and technologies that will result in better, cheaper, and faster site cleanups. Nanoremediation has the potential not only to reduce the overall cost of cleaning up large-scale contaminated sites, but it can also reduce clean-up time, eliminate the need for treatment and disposal of contaminated dredged soil, reduce some contaminant concentrations to near zero, and, what is more, can be carried out in situ. In situ nanoremediation methods involve the application of reactive nanomaterials for transformation and detoxification of pollutants in situ or below ground (Handy et al., 2008a). No groundwater is pumped out for aboveground treatment, and no soil is transported to other places for treatment and disposal. Because of the high cost and lengthy operating periods for pump-and-treat remedies, in situ groundwater treatment technologies are increasing. In addition to groundwater remediation, nanotechnology holds promise in reducing the presence of non-aqueous phase liquids. Recently, a material utilizing nano-sized oxides (mostly calcium) was used in situ to clean up heating oil spills from underground oil tanks. Preliminary results from this redox-based technology suggest faster, cheaper outcomes, and, ultimately, lower overall contaminant levels compared to previous remediation methods. Although the technology is likely a beneficial replacement of current practices for site remediation, potential risks are poorly understood. The factors and processes affecting ecotoxicity are complex, and knowledge of the potential impacts of manufactured NPs in the environment and on human health is still limited.

Nanotechnologies can be applied to water for different purposes as transport of organic or inorganic nutrients in nanocapsules or NPs (Acosta, 2009); modification of concentration and bioavailability of dissolved species (Borm et al., 2006); remediation of contaminated water

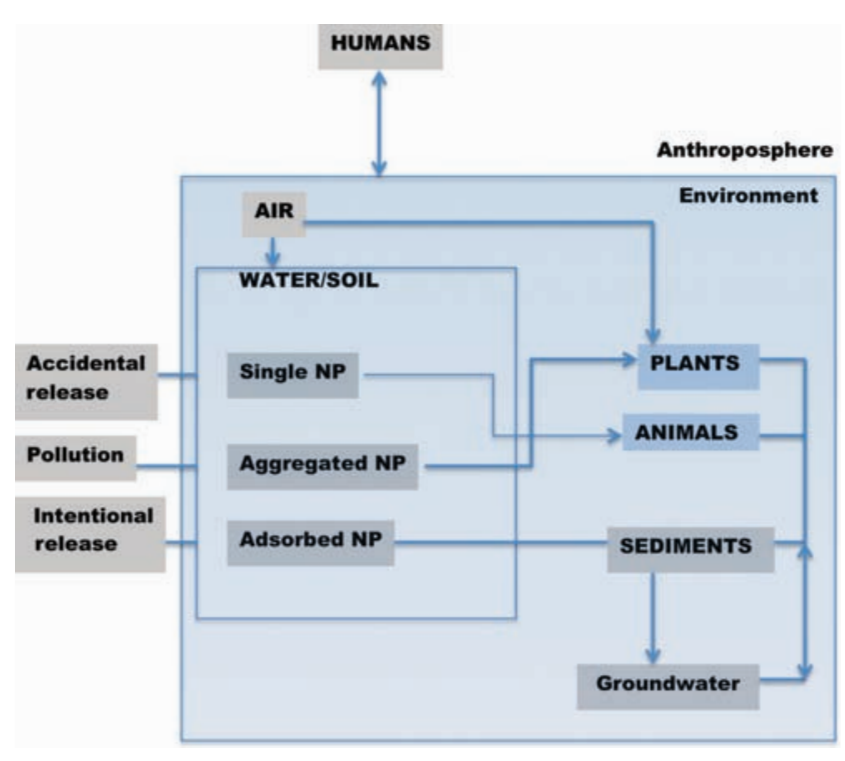

Figure 3. Occurrence, behaviour and effects of nanoparticles in the environment (from Nowack and Bucheli, 2007, with permission). NP, nanoparticle. 
and aquifers (Otto et al., 2008; Theron et al., 2008); detection of contaminants [pesticides, pathogens, polychlorinated biphenyls (PCBs), pollutants] (Zhang, 2010; Luo and Stutzenberger, 2008; Mura et al., 2012b). In particular, iron nanopowders can be used as effective nanoremediation tools for cleaning up contaminated soil and water (Nurmi et al., 2005). In fact, iron catalyses the oxidation and breakdown of organic contaminants (trichloroethene, carbon tetrachloride, dioxins, and PCBs) to simpler carbon compounds much less toxic (Wang and Zhang, 1997). Furthermore, it is extremely effective for binding and removing arsenic from groundwater, something that affects the water supply of millions of people in the developing world, and for which there is no effective existing solution (Kanel et al., 2006). Among some of the applications would be nanocomposites of dioxide of titanium, which in presence of ultraviolet (UV)-visible and solar light have bactericide and antiviral properties. Other application would be the hypercatalysis with palladium covered by gold NPs that would eliminate (Nutt et al., 2005; Senthilnathan and Ligy, 2010). A variety of nanomaterials is in various stages of research and development, each possessing unique functionalities that is potentially applicable to the remediation of industrial effluents, groundwater, surface water and drinking water. Nanoscale iron particles and their derivatives offer more alternatives to many remediation technologies. The small particle size of the nano iron $(1-100 \mathrm{~nm})$ facilitates a high level of remedial versatility. This allows a much greater diversity in applications as compared to the traditional ZVI employed in the PRB technology. Nanoscale ZVI and reactive nanoscale iron product are the most basic forms of the nano iron technology (www.epa.gov). The behavior of NPs in water is the same illustrated in the previous sections for soils but the use of these nano-compounds for water remediation could pave the way for a nano-aquaculture that would be beneficial for a large number of farmers across the world (Rather et al., 2011).

\section{Nanotechnologies for water purification}

Recently there has been increasing interest in the field of nanoapplication for water quality. Comba et al. (2011) demonstrated that chlorinated solvent contamination of aquifers can be efficiently treated by using ZVI. In particular, exploiting the synergistic effect of other methods, such as the association with microbial dechlorination, the performances of nanoscale iron were significantly improved. Some divalent heavy metal ions $[\mathrm{Cu}, \mathrm{Zn}, \mathrm{Pb}$, cadmium (Cd), cobalt $(\mathrm{Co})]$ were also removed from aqueous solutions using carbon nanotube sheets (Tofighy and Mohammadi, 2011; Lam et al., 2004) these were shown to be effective adsorbents for removal of heavy metal ions from water. To remove water borne pathogens, traditional methods used chlorinated compounds or ozonation that form dangerous byproducts (Shannon et al., 2008; Zhang et al., 2010). For this reason, a new method was recently developed that uses an alternative UV light combined with nanotechnologies to enhance the photon effect by mean of photocatalytic nanostructures. In fact, inorganic materials, such as transition metal oxides $\left(\mathrm{TiO}_{2} \mathrm{NPs}\right)$, are able to inactivate bacteria and viruses, generating oxygen-based radicals upon irradiation (Tayade $e t$ al., 2006; Mura et al., 2011b). These nanomaterials are not consumed during the process, as in the previous methods, and are, therefore, considered green technology for water disinfection. The increasing interest in this field led to the development of different UV and visible light driven water disinfection systems.

The principle of photocatalysis by applying metal oxides such as $\mathrm{TiO}_{2}, \mathrm{ZnO}, \mathrm{SnO}_{2}$ could also be used in the decomposition of toxic herbicides and pesticides, which under normal conditions take a long time to degrade (Malato et al., 2002). Successful results were reported for the degradation of some herbicides, such as dicamba (Prevot et al., 2001), 2,4-D (Herrmann and Guillard, 2000), atrazine (Zhanqi et al., 2007), and some pesticides, such as cyproconazole (Lhomme et al., 2007), carbofuran (Mahalakshmi et al., 2007), dichlorvos (Evgenidou et al., 2005), and 2,4-dichlorophenoxyacetic, also known as DPA (Shankar et al., 2004). To improve the action of nanomaterials, not only under UV light but also under visible light, nanomaterials were doped (Li et al., 2007; Wang et al., 2010) obtaining better antibacterial properties than in undoped materials (Dunnill et al., 2009; Shieh et al., 2006). This last innovation led to the development of a new photocatalyst (Li et al., 2010) consisting of palladium oxide (PdO) NPs well dispersed on a nitrogen-doped titanium oxide (TiON) matrix. In this case, a photoelectron transfer between PdO NPs and TiON was observed, obtaining an enhanced photocatalytic bacterial disinfection not only under visible light illumination but also in the dark, thanks to a unique catalytic memory effect due to the discharging of trapped electrons on PdO NPs. This was a very good result for the development of photocatalytic materials with 24-h active antibacterial effect. Recently, also other methods have been developed to remove pollutants and pathogens in water treatment, such as colossal magnet resistance materials, such as lanthanum calcium manganate (De et al., 2010) or silver NPs synthesised in a particular way (Krishnaraj et al., 2010). In all these cases, an inhibitory activity against water borne pathogens was demonstrated, but this was less effective than the previous photocatalysts. These encouraging results have aroused the interest of different companies in the field of water purification through nanotechnologies. For example, the US company Argonide has developed aluminium oxide nanofibres (NanoCeram), $2 \mathrm{~nm}$ in diameter, as a water purifier. Filters made from these fibres can remove viruses, bacteria and protozoan cysts from water. The future business fund of the German chemical group BASF (Ludwigshafen, Germany) has devoted a significant proportion of its 105 million US dollars to nanotechnology research for water purification. Commercial nanofiltration membranes (Boussu et al., 2007) with a pore size of 1.25-1.55 $\AA$ are currently produced and are available on the market. Altairnano's Nanocheck is a new commercial product that contains lanthanum NPs able to absorb phosphates from aqueous environments: applying these in ponds and swimming pools effectively removed available phosphates and prevented the growth of algae. The company expects this product to be commercially exploited by fish pond managers who spend huge amounts of money to remove algae from their ponds (Tiju and Morrrison, 2006).

\section{Nanotechnology for increasing soil water retention}

Different companies are starting to produce new nanomaterials to mitigate global problems such as the scarcity of water for irrigation (Wong and Karn, 2012). A nano-sand water repellent was developed to prevent water drainage in drylands and support the release of nutrients and molecules to support plant growth (Davidson and Gu, 2012). Each grain of sand is covered with a secret additive by simply laying down a $10 \mathrm{~cm}$ blanket of DIME (DIME Hydrophobic Materials, London, UK; http://www.dimecreations.com) hydrophobic material sand beneath desert topsoils. The treated sand is able to stop water drainage below the depth of the plant roots and maintains a subsurface water table, providing vegetation with a constant water supply. Other nanomaterials that have been recently developed are nanomembranes for water purification and desalination that would be several times more energy efficient, and nanoclays able to fixate the sand and increase the available water by $25 \%$ (DesertControl Inc., Vassoy, Norway; 
http://www.desertcontrol.com). The NanoClay works as a binder and keeps moisture in the sand. This means that plant roots will enjoy constant growth conditions and any plant able to survive under dry conditions will grow.

Revegetation of deserts by NanoClay could lead to mitigation of wind erosion, generate aggregates in the soil, and increase the amount of water available, thus improving growth of plants and trees. NanoClay is made up of clay minerals divided into their smallest components that are 0.7-1.5 nm thick, with a diameter of $20-300 \mathrm{~nm}$ and mixed with water. The test results of NanoClay, applied in hot, dry, sandy soil in Egypt, was an increase in yield of up to $416 \%$ while using only one-third of the normal consumption of irrigation water (Olesen, 2010).

An Iranian company, Zist Palayesh Zamin, followed a similar approach This company has stabilised sand dunes by means of nanopolymeric solvents to prevent environmental pollution and destruction of railroads and desert roads. The product contains ionised NPs enclosed by biopolymeric nanocoils (polylattice) that help to stabilise sand. All these new experiments underline the growing interest in the application of nanotechnologies, not only for water disinfection, but also for water retention, in order to overcome one of the main problems for developing countries: water sources.

\section{Nano-eco-toxicity effects on the environment}

Over recent years, there has been an increased awareness of the potential risks associated with manufactured nanomaterials (Handy et al., 2008b). Legally, manufactured nanomaterials are covered by the definition of substances as mentioned in the Registration, Evaluation, Authorisation and Restriction of Chemicals (REACH) legislation (European Commission, 2006). Risks associated with substances have to be evaluated. There have been several recent reviews of the emerging health issues concerning products of nanotechnologies (Colvin, 2003; Handy et al., 2012). Eco-toxic effects on environmental species have been demonstrated; aquatic species have been the most studied. One of the major problems in testing eco-toxicological fate and effects is the absence of consistent and broadly applicable information on how nanomaterials are to be suspended in the various exposure media used in testing. Particular attention needs to be paid to exposure media, how materials are mixed with the media, and the question of realistic exposures. A reduction in size to the nanoscale level results in an enormous increase in surface to volume ratio, so relatively more molecules of the chemical are present on the surface, thus increasing the intrinsic toxicity. This may be one of the reasons why NPs are generally more toxic than larger particles of the same insoluble material when compared on a mass dose base. The eco-toxicity is likely to be altered by environmental factors that influence the colloid behaviour of particles; these include $\mathrm{pH}$, ionic strength, divalent ions such as $\mathrm{Ca}^{2+}$, and the presence of organic matter (Handy et al., 2008a; Mühlfeld et al., 2008). Studies so far have collected information on the direct relevance to risk assessment, such as lethal concentration estimates, as well as fundamental research on possible mechanisms of toxicity, sub-lethal effects, and uptake processes. Existing risk assessment methods are generally applicable to nanomaterials, but specific aspects need to be developed (Shvedova et al., 2005). They include methods for both estimating exposure and identifying hazards. The highest potential risks come from free, insoluble NPs, either dispersed in a liquid or as dust. The most important properties of a nanomaterial to be characterised for risk assessment are: i) size and distribution of free particles and fibres/rods/tubes. These may be produced during the manufacture, use (including wear), and/or disposal/recycling of the nanoproduct; ii) specific surface area; iii) stability in relevant media (including the ability to aggregate and disaggregate); iv) surface adsorption properties; v) water solubility; vi) chemical reactivity.

The genotoxic effects of conventional particles are driven by two mechanisms: direct and indirect (mediated by inflammatory processes) (Gonzalez et al., 2008). One of the main limitations in the risk assessment of nanomaterials is the general lack of high-quality exposure and dosimetry data both for humans and for the environment. One of the issues is the difficulty in determining the presence of nanomaterials, and measuring them correctly on a routine basis in various substrates. In contrast to the other exposure routes, analytical instruments are generally available to determine exposure (size distribution of mass and number) for air-borne nanomaterials (Wallace et al., 2008). NPs may act via either of these pathways since they can cause inflammation and can also enter cells and cause oxidative stress (Federici $e t$ al., 2007). There is some evidence that their small size may allow NPs to penetrate into sub-cellular compartments such as the mitochondria and nucleus. The presence of nanomaterials in mitochondria and the nucleus can result in oxidative stress-mediated genotoxicity, and/or direct interaction with DNA (Colognato et al., 2008). For some manufactured nanomaterials, genotoxic activity has been reported, mainly associated to reactive oxygen species (ROS) generation, while for others contrasting results were obtained. Besides oxidative stress, additional mechanisms of genotoxicity that may be specific for nanomaterials also need to be considered, such as possible mechanical interferences during cell division, and other sources of genotoxic effects (i.e. metal release by nanomaterials).

The high presence of NPs in the environment can lead to toxic effects, and recent studies seem to suggest that their mechanism can be summarised as follows: i) NPs can generate reactive oxygen species (redox activity) and pose oxidative stress to organisms; ii) NPs can be adsorbed on cell membrane, disturbing its permeation properties, puncturing cell membrane, and interfering with physiological activities; iii) NPs could retain electrons and disturb electron transfer in organisms (phosphorylation and energy transfer); iv) NPs could interact with proteins and disturb the transfer of biosignals or gene information (Pan and Xing, 2010).

Although these seem to be the causes of toxicity, there are also some controversial results. In fact, nano $\mathrm{TiO}_{2}$ stimulates the growth of spinach when applied to the seeds or sprayed onto the leaves through the increased activity of several enzymes. It also promotes nitrate adsorption and enhances the efficiency of transforming inorganic nitrogen to organic nitrogen (Gao et al., 2005) but, at the same time, toxicity was reported for algae and daphnids (Hund-Rinke and Simon, 2006). Several authors showed that these results may be due to a lack of standard procedures of toxicity experiments for NPs. Therefore, experimental procedures such as NP preparation, selection of organism species, environmental conditions and toxicity testing need to be standardised (Handy et al., 2012).

\section{Nanoethics}

Nanotechnology is a part of our nation's future. Clearly this research could potentially be of great benefit to society through applications in agriculture and food systems. However, any new technology carries an ethical responsibility for its wise application and the recognition that there are potential unforeseen risks that may come with the enormous potential benefit (IRGC, 2006). One of the most important aspects of nanotechnology from an ethical point of view is the fact that nanomaterials show novel characteristics compared to the same material at a larger scale (Robison, 2011). In recent years, several authors have argued that the desirability of novel technologies should be assessed 
early, when they are still emerging. Such an ethical assessment of emerging technologies is by definition focused on an elusive object. Usually the estimated results, expectations, and benefits of the technology are taken as a starting point (Swierstra et al., 2009b). This jeopardises the traditional risk-assessment approach that has, in recent years, represented the most natural option in terms of environmental and other applied ethics, focusing on safety, environment and human health. Consequentialist nanoethics seem to move in a circle. On the one hand, we want to know whether researching into nanotechnology is morally right or wrong before we act. But, on the other hand, in order to make an ethical evaluation, we need to know about its consequences, and such knowledge is not going to be available without carrying out the very research that poses the ethical and moral dilemma. As Swiestra and Rip (2007) have pointed out, there are many argumentative schemes in nanoethics. Consequentialist argumentative schemes are fuelled by two general perspectives on technology: i) the optimistic view, claiming that technological progress is basically beneficial; and ii) the pessimistic view of technology, seen as inherently risky. Both perspectives come to terms with uncertainty in their own way. The optimistic view assumes that, in the long term, the new nanotechnology will be shown to be as beneficial as almost all other technology in human history, the presumption being that no technology is inherently morally bad, and that it is only the way it is used that can be drawn into question. The pessimistic view assumes on its side that we should mistrust progress, technology, and artificial, unnatural things and practices.

Along with consequentialist argumentative schemes, different nonconsequentialist schemes have emerged in nanotechnology, although they seem to be less popular and merely add to consequentialist schemes, for example, deontological arguments, justice arguments, good life arguments, etc. (Swiestra and Rip, 2007; Ferrari, 2010). Such argumentative schemes have actually faced the problem of uncertainty and ignorance by trying to scaling down the problem of risks and toxicity, and focusing on different ethically relevant aspects which are prior to or independent of the consequences (Swierstra et al., 2009a). However, non-consequentialist arguments, being a minority, reveal that the issue of consequences and risks in nanoethics cannot be satisfactorily bypassed. It is hard to accept that the right thing to do is to ban nanoresearch, also because we know that, if we do, someone elsewhere in the world will continue anyway. Consequently, one of the most reasonable objectives for future nanoethics should be to balance our goal of avoiding risks with the need for further research into nanotechnology in order to develop knowledge about its potential consequences, risks and toxicity.

\section{Conclusions}

Nanoscience includes the design of materials with virtually infinite possibilities. There is a clear need to test the safety of these new materials once exposed to the environment and living organisms, avoiding toxic materials and developing healthy alternatives. The potential positive benefits of these materials should be selected according to their impact on the environment and the human population. In particular, the intelligent use of nanomaterials can contribute to improve environmental quality and sustainability, to develop detection and sensing techniques for biological and chemical toxins, remediate and destroy the finest contaminants from water and soil, and discover green industrial processes that reduce energy consumption. The hazards identified indicate potential toxic effects of nanomaterials for man and the environment. However, it should be noted that not all nanomaterials induce toxic effects. Some manufactured nanomaterials have already been in use for a long time (e.g. carbon black, $\mathrm{TiO}_{2}$ ) and show low toxicity. Therefore, the hypothesis that smaller means more reactive, and thus more toxic, cannot be substantiated by the published data. For the moment, another important limitation for a wider application of nanomaterials in agriculture is the scale of production and the still prohibitive costs.

The potential for the application of nanotechnologies is enormous and much is still to be discovered. Given this, we need to study and understand the behaviour of these new materials. We also need to direct research in such a way as to help us make better choices and to promote less costly nanomaterial production and application procedures.

\section{References}

Acosta E, 2009. Bioavailability of NPs in nutrient and nutraceutical delivery. Curr. Opin. Colloid In. 14:3-15.

Balaji T, El-Safty SA, Matsunaga H, Hanaoka T, Mizukami F, 2006. Optical Sensors based on nanostructured cage materials for the detection of toxic metal ions. Angewandte Chemie. 118:7360-6.

Baruah S, Dutta J, 2009. Nanotechnology applications in pollution sensing and degradation in agriculture: a review. Environ. Chem. Lett. 7:191-204.

Ben-Moshe T, 2010. Transport of metal oxide nanoparticles in saturated porous media. Chemosphere 81:387-93.

Bergeson LL, 2010. Nanosilver pesticide products: what does the future hold? Environ. Qual. Manage. 19:73-82.

Borm P, Klaessig FC, Landry TD, Moudgil B, Pauluhn J, Thomas K, Trottier R, Wood S, 2006. Research strategies for safety evaluation of nanomaterials, part $\mathrm{V}$ : role of dissolution in biological fate and effects of nanoscale particles. Toxicol. Sci. 90:23-32.

Boussu K, De Baerdemaeker J, Dauwe C, Weber M, Lynn KG, Depla D, Aldea S, Vankelecom IFJ, Vandecasteele C, Van der Bruggen B, 2007. Physico-chemical characterization of nanofiltration membranes. Chem. Phys. Chem. 8: 370-9.

Bouwmeester H, Dekkers S, Noordam MY, Hagens WI, Bulder AS, de Heer C, ten Voorde SE, Wijnhoven SW, Marvin HJ, Sips AJ, 2009. Review of health safety aspects of nanotechnologies in food production. Regul. Toxicol. Pharmacol. 53:52-62.

Bradley EL, Castle L, Chaudhry Q, 2011. Applications of nanomaterials in food packaging with a consideration of opportunities for developing countries. Trends Food Sci. Technol. 22:604-10.

Buzea C, Pacheco Blandino I, Robbie K, 2007. Nanomaterials and nanoparticles: sources and toxicity. Biointerphases 2:MR17MR172.

Changa YC, Chen DH, 2005. Preparation and adsorption properties of monodisperse chitosan-bound $\mathrm{Fe}_{3} \mathrm{O}_{4}$ magnetic nanoparticles for removal of $\mathrm{Cu}$ (II) ions. J. Colloid Interf. Sci. 283:446-56.

Chen H, Yada R, 2011. Nanotechnologies in agriculture: New tools for sustainable development. Trends Food Sci. Tech. 22:585-94.

Christian P, Von der Krammer F, Baalousha M, Hofmann T, 2008. Nanoparticles: structure, properties, preparation and behaviour in environmental media. Ecotoxicology 17:326-43.

Colognato R, Bonelli A, Ponti J, Farina M, Bergamaschi E, Sabbioni E, 2008. Comparative genotoxicity of cobalt nanoparticles and ions on human peripheral leukocytes in vitro. Mutagenesis 23:377-82.

Colvin VL, 2003. The potential environmental impact of engineered nanoparticles. Nat. Biotechnol. 21:1166-70.

Comba S, Di Molfetta A, Sethi R, 2011. A comparison between field applications of nano-, micro-, and millimetric zero-valent iron for the remediation of contaminated aquifers. Water Air Soil Poll. 


\section{5:595-607.}

Corradini E., de Moura MR, Mattoso LHC, 2010. A preliminary study of the incorparation of NPK fertilizer into chitosan nanoparticles. Express Polym. Lett. 4:509-15.

Corredor E, Testillano PS, Coronado MJ, González-Melendi P, Fernández-Pacheco R, Marquina C, Ibarra MR, M de la Fuente J, Rubiales D, Pérezde-Luque A, Risueño MC, 2009. Nanoparticle penetration and transport in living pumpkin plants: in situ subcellular identification. BMC Plant Biol. 9:45-51.

Davidson D, Gu FX, 2012. Materials for sustained and controlled release of nutrients and molecules to support plant growth. J. Agric. Food. Chem. 60:870-6.

De D, Mandal SM, Gauri SS, Bhattacharya R, Ram S, Roy SK, 2010. Antibacterial effect of lanthanum calcium manganate nanoparticles against Pseudomonas aeruginosa. J. Biomed. Nanotechnol. 6:138-44.

Dunnill CWH, Aiken ZA, Pratten J, Wilson M, Morgan DJ, Parkin IP, 2009. Enhanced photocatalytic activity under visible light in $\mathrm{N}$ doped $\mathrm{TiO}_{2}$ thin films produced by APCVD preparations using tbutylamine as a nitrogen source and their potential for antibacterial films. J. Photoch. Photobio. A 207:244-53.

EFSA (European Food Safety Authority), 2009. The potential risks arising from nanoscience and nanotechnologies on food and feed safety - Scientific Opinion of the Scientific Committee (Question No EFSA-Q-2007-124a) - Adopted on 10 February 2009 EFSA J. 958:139.

El Asria S, Laghzizila A, Saoiabia A, Alaouib A, El Abassib K, M'hamdib $\mathrm{R}$, Coradinc T, 2009. A novel process for the fabrication of nanoporous apatites from Moroccan phosphaterock. Colloid. Surface A 350:73-8.

El-Salmawi KM, 2007. Application of polyvinyl alcohol (PVA) carboxylmethyl cellulose (CMC) hydrogel produced by conventional crosslinking or by freezing and tawing. J. Macromol. Sci. A. Pure Appl. Chem. 44:619-24.

European Commission, 2011. Commission recommendation of 18 October 2011 on the definition of nanomaterial, 2011/696/EU. In: Official Journal, L 275/38, 20/10/2011, available from: http://eurlex.europa.eu/LexUriServ/LexUriServ.do?uri=0J:L:2011:275:0038:0 040:EN:PDF

European Commission, 2006. Regulation (EC) No 1907/2006 of the European Parliament and of the Council of 18 December 2006 concerning the Registration, Evaluation, Authorisation and Restriction of Chemicals (REACH), establishing a European Chemicals Agency, amending Directive 1999/45/EC and repealing Council Regulation (EEC) No 793/93 and Commission Regulation (EC) No 1488/94 as well as Council Directive 76/769/EEC and Commission Directives 91/155/EEC, 93/67/EEC, 93/105/EC and 2000/21/EC. In: Official Journal, L 396/1, 30/12/2006, available from: http://eur-lex.europa.eu/LexUriServ/LexUriServ.do?uri=0j:l:2006: 396:0001:0849:en:pdf

Evgenidou E, Fytianos K, Poulios, 2005. Semiconductor-sensitized photodegradation of dichlorvos in water using $\mathrm{TiO}_{2}$ and $\mathrm{ZnO}$ as catalysts. Appl. Catal. B Environ. 59:81-9.

Fang J, Shan XQ, Wen B, Lin JM, Owens G, 2009. Stability of titania nanoparticles in soil suspensions and transport in saturated homogeneous soil columns. Environ. Pollut. 157:1101-9.

FAO/WHO, 2010. Expert Meeting on the application of nanotechnologies in the food and agriculture sectors: potential food safety implications. Food and Agriculture Organization of the United Nations and World Health Organization, Rome, Italy. Available from: http:// www.fao.org/docrep/012/i1434e/i1434e00.pdf

Federici G, Shaw BJ, Handy RD, 2007. Toxicity of titanium dioxide to rainbow trout (Oncorhynchus mykiss): gill injury, oxidative stress, and other physiological effects. Aquat. Toxicol. 84:415-30.

Feehan J, Harley M, Minnen J, 2009. Climate change in Europe. 1. Impact on terrestrial ecosystems and biodiversity. A review. Agron. Sustain. Dev. 29:409-21.

Ferrari A, 2010. Developments in the debate on nanoethics: traditional approaches and the need for a new kind of analysis. Nanoethics 4:27-52.

Fiorani D, 2005. Nanostructure science and technology. Surface effects in magnetic nanoparticles, XIV. 300 p.

Gao YJ, Li SX, Li SQ, Tian XH, Wang CH, Zheng XF, Du JJ, 2005. Effect of fertilization and irrigation on residual nitrate $\mathrm{N}$ in soil. J. Soil Water Conserv. 9:61-4.

Gardea-Torresdey JL, Parsons JG, Gomez E, Peralta-Videa J, Troiani HE, Santiago P, Yacaman MJ, 2002. Formation and growth of $\mathrm{Au}$ nanoparticles inside live alfalfa plants. Nano Lett. 2:397-401.

Ge Y, Schimel JP, Holden PA, 2011. Evidence for negative effects of $\mathrm{TiO}_{2}$ and $\mathrm{ZnO}$ nanoparticles on soil bacterial communities. Environ. Sci. Technol. 45:1659-64.

Ghormade V, Deshpande MV, Paknikar KM, 2010. Perspectives for nanobiotechnology enabled protection and nutrition of plants. Biotechnol. Adv. 29:792-803.

Gilbert B, Zhang H, Huang F, Finnegan MP, Waychunas GA, Banfield JF, 2003. Special phase transformation and crystal growth pathways observed in nanoparticles. Geochem. Trans. 4:20-28.

Gonzalez L, Lison D, Kirsch-Volders M, 2008. Genotoxicity of engineered nanomaterials: a critical review. Nanotoxicology. 2:252-73.

Gonzalez-Melendi P, Fernandez-Pacheco R, Coronado MJ, 2008. Nanoparticles as smart treatment-delivery systems in plants: assessment of different techniques of microscopy for their visualization in plant tissues. Ann. Bot-London. 101:187-95.

Grieger KD, Fjordbøge A, Hartmann NB, Eriksson E, Bjerg PL, Baun A, 2010. Environmental benefits and risks of zero-valent iron nanoparticles (nZVI) for in situ remediation: risk mitigation or trade-off? J. Contam. Hydrol. 118:165-83.

Han J, Fu J, Schoch RB, 2008. Molecular sieving using nanofilters: past, present and future. Lab Chip. 8:23-33.

Handy RD, Cornelis G, Fernandes T, Tsyusko 0, Decho A, Sabo-Attwood T, Metcalfe C, Steevens JA, Klaine SJ, Koelmans AA, Horne N, 2012. Ecotoxicity test methods for engineered nanomaterials: practical experiences and recommendations from the bench. Environ. Toxicol. Chem. 31:15-31.

Handy RD, Henry TB, Scown TM, Johnstone BD, Tyler CR, 2008a. Manufactured nanoparticles: their uptake and effects on fish: a mechanistic analysis. Ecotoxicology 17:396-409.

Handy RD, Owen R, Valsami-Jones E, 2008b. The ecotoxicology of nanoparticles and nanomaterials: current status, knowledge gaps, challenges, and future needs. Ecotoxicology 17:315-25.

Hassellöv M, Readman JW, Ranville JF, Tiedje K, 2008. Nanoparticle analysis and characterization methologies in environmental risk assessment of engineered nanoparticles. Ecotoxicology 17:344-61.

Haverkamp RG, Marshall AT, van Agterveld D, 2007. Pick your carats: nanoparticles of gold-silver-copper alloy produced in vivo. J. Nanopart. Res. 9:697-700.

Heckmann LH, Hovgaard MB, Sutherland DS, Autrup H, Besenbacher F, Scott-Fordsmand JJ, 2011. Limit-test toxicity screening of selected inorganic nanoparticles to the earthworm Eisenia fetida. Ecotoxicology 20:226-233.

Herrmann JM, Guillard C, 2000. Photocatalytic degradation of pesticides in agricultural used waters. Surface Chem. Catalysis 23:417.

Hillie T, Hlophe M, 2007. Nanotechnology and the challenge of clean water. Nat. Nanotechnol. 2:663-4.

Hund-Rinke K, Simon M, 2006. Ecotoxic effect of photocatalytic active nanoparticles $\left(\mathrm{TiO}_{2}\right)$ on algae and daphnids. Environ. Sci. Pollut. 
Res. Int. 13:225-32.

IRGC (International Risk Governance Council), 2006. White paper on nanotechnology risk governance. Geneva: International Risk Governance Council. Available from: http://irgc.org/wp-content/ uploads/2012/04/IRGC_white_paper_2_PDF_final_version-2.pdf

Jianhui Y, Kelong H, Yuelong W, Suqin L, 2005. Study on anti-pollution nanopreparation of dimethomorph and its performance. Chin. Sci. Bull. 50:108-12.

Jinghua G, 2004. Synchrotron radiation, soft X-ray spectroscopy and nano-materials. J. Nanotechnol. 1:193-225.

Johnston CT, 2010. Probing the nanoscale architecture of clay minerals. Clay Miner. 45:245-79.

Jones A, Stolbovoy V, Rusco E, Gentile AR, Gardi C, Marechal B, Montanarella L, 2009. Climate change in Europe. 2. Impact on soil. A review. Agron. Sustain. Dev. 29:423-32.

Kanel SR, Grenèche JM, Choi H, 2006. Arsenic (V) Removal from groundwater using nano scale zero-valent iron as a colloidal reactive barrier material. Environ. Sci. Technol. 40:2045-50.

Karn B, Kuiken T, Otto M, 2009. Nanotechnology and in situ remediation: a review of the benefits and potential risks. Environ. Health Perspect. 117:1813-31.

Kellogg CA, Griffin DW, 2006. Aerobiology and the global transport of desert dust. Trends Ecol. Evol. 21:638-44.

Khodakovskaya M, Dervishi E, Mahmood M, Xu Y, Li Z, Watanabe F, Biris AS, 2009. Carbon nanotubes are able to penetrate plant seed coat and dramatically affect seed germination and plant growth. ACS Nano 3:3221-7.

Khot LR, Sankaran S, Maja JM, Ehsani R, Schuster EW, 2012. Applications of nanomaterials in agricultural production and crop protection: a review. Crop Prot. 35:64-70.

Kim S, Kim J, Lee I, 2011. Effects of Zn and Zn0 nanoparticles and Zn ${ }^{2+}$ on soil enzyme activity and bioaccumulation of $\mathrm{Zn}$ in Cucumis sativus. Chem. Ecol. 27:49-55.

Klaine SJ, Avarez PJ, Batley GE, Fernandes TF, Handy RD, Lyon DY, 2008. Nanomaterials in the environment: behavior, fate, bioavailability, and effects. Environ. Toxicol. Chem. 27:1825-51.

Krishnaraj C, Jagan EG, Rajasekar S, Selvakumar P, Kalaichelvan PT, Mohan N, 2010. Synthesis of silver nanoparticles using Acalypha indica leaf extracts and its antibacterial activity against water borne pathogens. Colloid. Surf. B 76:50-6.

Kumar J, Shakil NA, Singh MK, Singh MK,Pandey A, Pandey RP, 2010. Development of controlled release formulations of azadirachtin-A employing poly(ethylene glycol) based amphiphilic copolymers. J. Environ. Sci. Health B. 45:310-4.

Lal R, 2007. Soil science and the carbon civilization. Soil Sci. Soc. Am. J. 71:1425-37.

Lam CW, James JT, McCluskey R, Hunter RL, 2004. Pulmonary toxicity of single-wall carbon nanotubes in mice 7 and 90 days after intratracheal instillation. Toxicol. Sci. 77:126-34.

Lee J, Mahendra S, Alvarez PJJ, 2010. Nanomaterials in the construction industry: a review of their applications and environmental health and safety considerations. ACS Nano 4:3580-90.

Lhomme L, Brossilon S, Woolbert D, 2007. Photocatalytic degradation of a triazole pesticide, cyproconazole, in water. J. Photochem. Photobiol. 188:34-42.

Li Q, Li YW, Liu Z, Xie R, Shang JK, 2010. Memory antibacterial effect from photoelectron transfer between nanoparticles and visible light photocatalyst. J. Mater. Chem. 20:1068-72.

Li Q, Mahendra S, Lyon DY, Brunet L, Liga MV, Li D, Alvarez PJJ, 2008. Antimicrobial nanomaterials for water disinfection and microbial control: potential applications and implications. Water Res. 42:4591-602.

Li Q, Xie R, Li YW, Mintz EA, Shang JK, 2007. Enhanced visible-light-
Induced photocatalytic disinfection of E. coli by carbon-sensitized nitrogen-doped titanium oxide. Environ. Sci. Technol. 41:5050-6.

Lin D, Xing B, 2007. Phytotoxicity of nanoparticles: inhibition of seed germination and root growth. Environ. Pollut. 150:243-50.

Liu X, Feng Z, Zhang S, Zhang J, Xiao Q, Wang Y, 2006. Preparation and testing of cementing nano-subnano composites of slower controlled release of fertilizers. Scientia Agricultura Sinica 39:1598604.

Lü QF, Huang MR, Li XG, 2007. Synthesis and heavy metal ion sorption of pure sulfophenylenediamine copolymer nanoparticles with intrinsic conductivity and stability. Chem. Eur. J. 13:6009-18.

Luo PG, Stutzenberger FJ, 2008. Nanotechnology in the detection and control of microorganisms. Adv. Appl. Microbiol. 63:145-73.

Ma X, Geiser-Lee J, Deng Y, Kolmakov A, 2010a. Interactions between engineered nanoparticles (ENPs) and plants: Phytotoxicity, uptake and accumulation. Sci. Total Environ. 408:3053-61.

Ma Y, Kuang L, HeX, Bai W, Ding Y, Zhang Z, Zhao Y, Chai Z, 2010b. Effects of rare earth oxide nanoparticles on root elongation of plants. Chemosphere 78:273-9.

Mahalakshmi M, Arabindoo B, Palanichamy M, Murugesan V, 2007. Photocatalytic degradation of carbofuran using semiconductor oxides. J. Hazard Mater. 143:240-5.

Malato A, Blanco J, Vidal A, Richter C, 2002. Photocatalysis with solar energy at a pilot-plant scale: an overview. Appl. Catal. B-Environ. 37:1-15.

Martinson CA, Reddy KJ, 2009. Adsorption of arsenic (III) and arsenic (V) by cupric oxide nanoparticles. J. Colloid Interf. Sci. 336:406-11.

Marchiol L, 2012. Synthesis of metal nanoparticles in living plants. Ital. J. Agron. 7:e37.

Maurice PA, Hochella MF, 2008. Nanoscale particles and processes: a new dimension in soil science. Adv. Agron. 100:123-38.

Mercier L, Pinnavaia TJ, 1997. Access in mesoporous materials: advantages of a uniform pore structure in the design of a heavy metal ion adsorbent for environmental remediation. Adv. Mater. 9:500-3.

Miller G, Senjen R, 2008. Out of the laboratory and on to our plates. Nanotechnology in food \& agriculture. In: Friends of the Earth, Australia, Europe \& U.S.A. Available from: http//www.foeeurope. org/activities/nanotechnology/Documents/Nano_food_report.pdf

Mühlfeld C, Gehr P, Rothen-Rutishauser B, 2008. Translocation and cellular entering mechanisms of nanoparticles in the respiratory tract. Swiss Med. Wkly. 138:387-91.

Mueller N, Nowack B, 2010. Nanoparticles for remediation: solving big problems with little particles. Elements 6:395-400.

Mura S, Corrias F, Stara G, Piccinini M, Secchi N, Marongiu D, Innocenzi P, Irudayaraj J, Greppi GF, 2011a. Innovative composite films of chitosan, methylcellulose and nanoparticles. J. Food Sci. 76:54-60.

Mura S, Greppi GF, Innocenzi P, Piccinini M, Figus C, Marongiu ML, Guo C, Irudayaraj J, 2012a. Nanostructured thin films as surfaceenhanced Raman scattering substrates. J. Raman Spectroscopy 44:35-40.

Mura S, Greppi GF, Marongiu M, Roggero PP, Ravindranath SP, Mauer LJ, Schibeci N, Perria F, Piccinini M, Innocenzi P, Irudayaraj J, 2012b. FTIR-nanobiosensors for Escherichia coli detection. Beilstein J. Nanotechn. 3:485-92.

Mura S, Greppi GF, Roggio A, Malfatti L, Innocenzi P, 2011b. Polypeptide binding to mesostructured titania films. Microporous Mesoporous Mat. 142:1-6.

Mura S, Irudayaraj J, Greppi GF, 2011c. Biosensors in real time for the identification of environmental toxins. pp 380-381 in Proc. 40th Meet. SIA, Teramo, Italy.

Murr LE, Esquivel EV, Bang JJ, de la Rosa G, Gardea-Torresdey JL, 2004. Chemistry and nanoparticulate compositions of a 10,000 year-old 
ice core melt water. Water Res. 38:4282-96.

Murr LE, Garza KM, 2009. Natural and anthropogenic environmental nanoparticulates: their microstructural characterization and respiratory health implications. Atmos. Environ. 43:2683-92.

Nair R, Varguese SH, Nair BG, Maekawa T, Yoshida Y, Kumar DS, 2010. Nanoparticulate material delivery to plants. Plant Sci. 179:154-63.

Nowack B, Bucheli TD, 2007. Occurrence, behavior and effects of nanoparticles in the environment. Environ. Pollut. 150:5-22.

Nurmi JT, Tratnyek PG, Sarathy V, Baer DR, Amonette JE, Pecher K, Wang C, Linehan JC, Matson DW, Penn RL, Driessen MD, 2005. Characterization and properties of metallic iron nanoparticles: spectroscopy, electrochemistry, and kinetics. Environ. Sci. Technol. 39:1221-30.

Nutt MO, Hughes, JH, Wong, MS, 2005. Designing Pd-on-Au bimetallic nanoparticle catalysts for trichloroethene hydrodechlorination. Environ. Sci. Technol. 39:1346-53.

Olesen KP, 2010. Turning sandy soil to farmland: $66 \%$ water saved in sandy soil treated with NanoClay. Vassoy: Desert Control Institute Inc., pp. 10. Available from: http://www.desertcontrol.com

Otto M, Floyd M, Bajpai S, 2008. Nanotechnology for site remediation. Remediation J. 19:99-108.

Pan B, Xing B, 2010. Manufactured nanoparticles and their sorption of organic chemicals. Adv. Agr. 108:137-81.

Park KH, 2006. Korea Patent Application: WPI ACC NO: 2006489267/200650. Preparation method antibacterial wheat flour by using silver nanoparticles.

Perez-de-Luque A, Rubiales D, 2009. Nanotechnology for parasitic plant control. Pest Manag. Sci. 65:540-45.

Ponder SM, Darab JG, Bucher J, Caulder D, Craig I, Davis L, Edelstein N, Lukens W, Nitsche H, Rao L, Shuh DK, Mallouk TE, 2001. Surface chemistry and electrochemistry of supported zerovalent iron nanoparticles in the remediation of aqueous metal contaminants. Chem. Mater. 13:479-86.

Prevot AB, Fabbri D, Pramauro E, Rubio AM, de la Guardia M, 2001. Continuous monitoring of photocatalytic treatments by flow injection. Degradation of dicamba in aqueous $\mathrm{TiO}_{2}$ dispersions. Chemosphere 44:249-55.

Qafoku NP, 2010. Terrestrial nanoparticles and their controls on soilgeo-processes and reactions. Adv. Agron. 107:33-91.

Rather MA, Sharma R, Aklakur M, Ahmad S, Kumar N, Khan M, Ramya VL, 2011. Nanotechnology: a novel tool for aquaculture and fisheries development. A prospective mini-review. Fish. Aquacult. J. 2011:FAJ-16.

Robison WL, 2011. Nano-technology, ethics and risks. Nanoethics 5:113.

RSRAE (The Royal Society \& Royal Academy of Engineering), 2004. Nanoscience and nanotechnologies: opportunities and uncertainties. RS Policy document 19/04. Royal Society, London. Available from: http://www.royalsoc.ac.uk

Scherer MM, Richter S, Valentine RL, Alvarez PJJ, 2000. Chemistry and microbiology of permeable reactive barriers for in situ groundwater clean up. Crit. Rev. Env. Sci. 30:363-411.

Schroeder J, Thomas H, Murray LW, 2005. Impacts of crop pests on weeds and weed-crop interactions. Weed Sci. 53:918-22.

Scott NR, Chen H, 2003. Nanoscale science and engineering or agriculture and food systems. In: Roadmap Report of National Planning Workshop. Washington D.C. Available from: http://www.nseafs.cornell.edu/web.roadmap.pdf

Senthilnathan J, Ligy P, 2010. Removal of mixed pesticides from drinking water system using surfactant-assisted nano-TiO ${ }_{2}$. Water Air Soil Poll. 210:143-65.

Shankar MV, Anandan S, Venkatachalam N, Arabindoo B, Murugesan V, 2004. Novel thin-film reactor for photocatalytic degradation of pes- ticides in an aqueous solution. J. Chem. Technol. Biot. 79:1279-85.

Shannon MA, Bohn PW, Elimelech M, Georgiadis JG, Mariñas BJ, Mayes AM, 2008. Science and technology for water purification in the coming decades. Nature 452:301-10.

Shieh KJ, Li M, LeeYH, Sheu SD, Liu YT, Wang YC, 2006. Antibacterial performance of photocatalyst thin film fabricated by defection effect in visible light. Nanomed-Nanotechnol. 2:121-6.

Shoults-Wilson WA, Zhurbich OI, McNear DH, Tsyusko OV, Bertsch PM, Unrine JM, 2011. Evidence for avoidance of Ag nanoparticles by earthworms (Eisenia fetida). Ecotoxicology 20:385-96.

Shvedova AA, Kisin ER, Mercer R, Murray AR, Johnson VJ, Potapovich AI, Tyurina YY, Gorelik 0, Arepalli S, Schwegler-Berry D, Hubbs AF, Antonini J, Evans DE, Ku BK, Ramsey D, Maynard A, Kagan VE, Castranova V, Baron P, 2005. Unusual inflammatory and fibrogenic pulmonary responses to single-walled carbon nanotubes in mice. Am. J. Physiol. Lung C. 289:698-708.

Sidorenko A, Tokarev I, Minko S, Stamm M, 2003. Ordered reactive nanomembranes nanotemplates from thin films of block copolymer supramolecular assembly. J. Am. Chem. Soc. 125:12211-6.

Siegmann P, Acevedo FJ, Siegmann K, Maldonado-Bascón S, 2008. A probabilistic source attribution model for nanoparticles in air suspension applied on the main roads of Madrid and Mexico City. Atmos. Environ. 42:3937-48.

Sinha RK, 2009. The concept of sustainable agriculture: an issue of food safety \& security for people, economic prosperity for the farmers and ecological security for the nations. American-Eurasian J. Agric. Environ. Sci. 5:1-4.

Swierstra T, Rip A, 2007. Nano-ethics as NEST-ethics: patterns of moral argumentation about new and emerging science and technology. NanoEthics 1:3-20.

Swierstra T, Stemerding D, Boenink M, 2009a. Exploring techno-moral change: the case of the obesitypill. In: P. Sollie, M. Düwell (eds) Evaluating new technologies. Vol. 3, Springer, Berlin, Heidelberg, Germany, pp 119-138.

Swierstra T, van Est R, Boenink M, 2009b. Taking care of the symbolic order. How converging technologies challenge our concepts. NanoEthics 3:269-80.

Tayade RJ, Kulkarni RG, Jasra RV, 2006. Transition metal ion impregnated mesoporous $\mathrm{TiO}_{2}$ for photocatalytic degradation of organic contaminants in water. Ind. Eng. Chem. Res. 45:5231-8.

Taylor NJ, Fauquet CM, 2002. Microparticle bombardment as a tool in plant science and agricultural biotechnology. DNA Cell Biol. 21:96377.

Theron J, Walker JA, Cloete TE, 2008. Nanotechnology and water treatment: applications and emerging opportunities. Crit. Rev. Microbiol. 34:43-69.

Tiede K, Boxall A, Tear S, Lewis J, David H, Hassellöv M, 2008. Detection and characterization of engineered nanoparticles in food and the environment. Food Addit. Contam. Part A Chem. Anal. Control Expo. Risk Assess. 25:795-821.

Tiju J, Morrison M, 2006. A Nanoforum report. Nanotechnology in Agriculture and Food. Available from: ftp://ftp.cordis.europa. eu/pub/nanotechnology/docs/nanotechnology_in_agriculture_and food.pdf

Tofighy MA, Mohammadi T, 2011. Adsorption of divalent heavy metal ions from water using carbon nanotube sheets. J. Hazard. Mater. 185:140-7.

Torney F, Trewyn BG, Lin VS-Y, Wang K, 2007. Mesoporous silica nanoparticles deliver DNA and chemicals into plants. Nature Nanotech. 2:295-300.

Tourinho PS, van Gestel CAM, Lofts S, Svendesen C, Soares AMVM, Loureiro S, 2012. Metal-based nanoparticles in soil: fate, behavior and effects on soil invertebrates. Environ. Toxicol. Chem. 31:1679- 
92.

Tungittiplakorn W, Cohen C, Lion LV, 2005. Engineered polymeric nanoparticles for bioremediation of hydrophobic contaminants. Environ. Sci. Technol. 39:1354-8.

USDA (United States Department of Agriculture), 2003. Nanoscale science and engineering for agriculture and food systems. United States Department of Agriculture, Washington, DC, USA.

Verma HC, Upadhyay C, Tripathi A, Tripathi RP, Bhandari N, 2002. Thermal decomposition pattern and particle size estimation of iron minerals associated with the cretaceous-tertiary boundary at Gubbio. Meteorit. Planet Sci. 37:901-9.

Wallace L, Wang F, Howard-Reed C, Persily A, 2008. Contribution of gas and electric stoves to residential ultrafine particle concentrations between 2 and 64nm: size distributions and emissions and coagulation rates. Environ. Sci. Technol. 42:8641-7.

Wang CB, Zhang WX, 1997. Synthesizing Nanoscale iron particles for rapid and complete dechlorination of TCE and PCBs. Environ. Sci. Technol. 31:2154-6.

Wang Z, Lee YH, Wu B, Horst A, Kang Y, Tang YJ, Chen DR, 2010. Antimicrobial activities of aerosolized transition metal oxide nanoparticles. Chemosphere 80:525-9.

Wei C, Yamato M, Wei W, Zhao X, Tsumoto K, Yoshimura T, Ozawa T, Chen, Y.J., 2007. Genetic nanomedicine and tissue engineering. Med. Clin. North Am. 91:889-98.

Wong S, Karn B, 2012. Ensuring sustainability with green nanotechnol- ogy. Nanotechnology 27:23-9.

Woodrow Wilson International Centre for Scholars, 2009. The Nanotechnology Consumer Inventory. Available from: http://www. nanotechproject.org/inventories/consumer/

Yang K, Zhu L, Xing B, 2006. Adsorption of polycyclic aromatic hydrocarbons by carbon nanomaterials. Environ. Sci. Technol. 40:185561 .

Yuan GD, 2004. Natural and modified nanomaterials as sorbents of environmental contaminants. J. Env. Sci. Health 39:2661-70.

Zhan J, 2009. Multifunctional colloidal particles for in situ remediation of chlorinated hydrocarbons. Environ. Sci. Technol. 43:8616-21.

Zhang W, 2010. Nanoscale iron particles for environmental remediation: an overview. J. Nanopart. Res. 5:323-32.

Zhang D, Li G, Yu JC, 2010. Inorganic materials for photocatalytic water disinfection. J. Mater. Chem. 20:4529-36.

Zhang F, Wang, R, Xiao Q, Wang Y, Zhang J, 2006. Effects of slow/controlled-release fertilizer cemented and coated by nano-materials on biology. II. Effects of slow/controlled-release fertilizer cemented and coated by nano-materials on plants. Nanoscience 11:18-26.

Zhanqi G, Shaogui Y, Na T, Cheng S, 2007. Microwave-assisted rapid and complete degradation of atrazine using $\mathrm{TiO}_{2}$ nanotube photocatalyst suspensions. J. Hazard. Mater. 145:424-30.

Zheng L, Hong F, Lu S, Liu C, 2005. Effect of nano-TiO ${ }_{2}$ on strength of naturally aged seeds and growth of spinach. Biol. Trace Elem. Res. 104:83-91. 